\title{
The Surface Properties of Neisseria gonorrhoeae: Isolation of the Major Components of the Outer Membrane
}

\author{
By J. E. HECKELS \\ Microbiology - Faculty of Medicine, Southampton General Hospital, \\ Southampton SO9 $4 X Y$
}

(Received 8 November 1976)

\begin{abstract}
SUMMARY
Outer membranes were isolated from several strains of Neisseria gonorrhoeae by extraction of whole cells with aqueous lithium acetate. The preparations contained a limited number of components including lipopolysaccharide and two major proteins. One protein was present in all strains examined; the second, which showed anomalous behaviour on sodium dodecyl sulphate-polyacrylamide gel electrophoresis, was absent from some. Fluorescent labelling of intact $N$. gonorrhoeae showed that the two proteins and pili were the major surface proteins. Each of the three major outer membrane components was isolated in a homogeneous form by selective extraction followed by gel filtration.
\end{abstract}

\section{INTRODUCTION}

The surface components of virulent bacteria play an important role in the pathogenesis of disease acting, for example, as major antigens and as mediators of attachment to host cell surfaces. With Neisseria gonorrhoeae (gonococci), pili and the outer membrane layer of the cell envelope have been implicated in these roles. Pili, which are associated with enhanced virulence in humans (Kellogg et al., 1963), are responsible for increased attachment in vitro, probably by overcoming the initial electrostatic repulsive force between the gonococcus and its host cell (Heckels et al., 1976). Raised levels of anti-pilus antibodies have been reported in patients with gonorrhoea, an observation which suggests that the detection of such antibodies might provide a serological screening system (Buchanan et al., 1973).

The outer membrane of $N$. ganorrhoeae has been isolated and, like that of other Gramnegative bacteria, it is composed of lipopolysaccharide (LPS), phospholipids and a limited number of proteins (Johnston \& Gotschlich, 1974; Wolf-Watz et al., 1975). A complex derived from the outer membrane has been used to subdivide gonococci into serologically distinct groups based on the antigenic specificity of a major outer membrane protein (Johnston, Holmes \& Gotschlich, 1976). The outer membrane must also be involved in the firm adhesion between gonococci and host cells. There is little information on the individual components involved in adhesion, but blocking of charged groups on the gonococcal surface proteins did not inhibit attachment in vitro (Heckels et al., 1976).

Studies on the contribution of surface components to the immune response have been complicated by the polyantigenic nature of gonococci and the difficulty of preparing homogeneous antigens. Thus pilus preparations used in serological studies contained contaminating LPS (Novotny \& Turner, 1975), and although the outer membrane complex similarly used contained one major protein, significant amounts of LPS and a secondary protein were present (Johnston et al., 1976). For this reason our approach to the study of 
the role of gonococcal surface components in the pathogenesis of gonorrhoea has been to isolate initially the individual components in a pure form as a prelude to immunological and attachment studies. Thus pili have been purified by disaggregation and isopycnic centrifugation (Ward \& Robertson, 1976) and LPS has been isolated from phenol/water extracts of whole cells (Stead et al., 1975). The present study describes relatively mild procedures for isolating LPS and two major proteins from the outer membrane of Neisseria go norrhoeae.

\section{METHODS}

Growth and harvesting. Neisseria gonorrhoeae strains were from several sources. Strains P9 and F62 have been maintained in this laboratory for some years, strains 24445, 24382, 24606, 24207 and 1722 I were recent isolates stored in liquid nitrogen after minimum subculture, strain FA5 was obtained from Dr P. F. Sparling, University of North Carolina, U.S.A., and strain 201 was from Dr K. K. Holmes, University of Washington School of Medicine, Seattle, U.S.A.

Bacteria were grown overnight on $74 \mathrm{~cm}$ plates of Bacto GC medium base (Difco) supplemented as described by White \& Kellogg(1965). Organisms from I00 plates were removed by suspension in ice-cold $0.01 \mathrm{M}-\mathrm{Tris} / \mathrm{HCl}$ buffer, $\mathrm{pH} 8.0$, and recovered by centrifugation at $10000 \mathrm{~g}$ for $30 \mathrm{~min}$. In some experiments pili were removed from gonococci by shearing (Ward \& Robertson, 1976) before extraction of the outer membrane.

Isolation of the outer membrane complex. The outer membrane complex was removed from bacteria by a method based on that of Johnston et al. (1976). Bacteria were suspended in $0.3 \mathrm{M}$-lithium acetate $\mathrm{pH} 6.0$ at a concentration of about $2 \%(\mathrm{w} / \mathrm{v})$ and shaken at $45^{\circ} \mathrm{C}$ for $2.5 \mathrm{~h}$. The suspension was then homogenized for $\mathrm{I} \min$ in a Vortex mixer with a blade clearance of $0.025 \mathrm{~mm}$ (P. Silver and Sons, Hampton). Bacteria were removed by centrifuging at $15000 \mathrm{~g}$ for $20 \mathrm{~min}$ and the supernatant solution was centrifuged three more times to remove traces of debris. The clear supernatant solution was centrifuged at $100000 \mathrm{~g}$ for $2.5 \mathrm{~h}$; the resulting translucent pellet was washed twice with $0.2 \mathrm{M}$-acetate buffer $\mathrm{pH} 5.8$, resuspended in the same buffer and stored at $-20{ }^{\circ} \mathrm{C}$ until required.

Density gradient centrifugation. Membranes suspended in $0.8 \mathrm{M}$-sucrose and $5 \mathrm{~mm}$ EDTA in I0 $\mathrm{mm}$-Tris/HCl buffer, $\mathrm{pH} 7.0$, were applied to a discontinuous gradient of $60 \%$ to $20 \%(\mathrm{w} / \mathrm{w})$ sucrose solution and centrifuged at $250000 \mathrm{~g}$ for $\mathrm{I} 8 \mathrm{~h}$ as described by Johnston \& Gotschlich (1974). The tube contents were removed by upward displacement with $60 \%(\mathrm{w} / \mathrm{w})$ sucrose solution; the fractions collected were analysed for proteins and the buoyant density of the single outer membrane band was determined.

Fluorescent labelling of cells and the outer membrane complex. Neisseria gonorrhoeae P9 was suspended in $0.1 \mathrm{M}$-phosphate buffer $\mathrm{pH} 7.6(\mathrm{I} 2 \mathrm{ml})$ so that a 10 -fold dilution had an $E_{800}^{\mathrm{Icm}}$ of $\mathrm{I} \cdot \mathrm{O}$. Homogeneous dansyl chloride-cycloheptaamylose reagent was prepared according to the method of Kinoshita, linuma \& Tsuji (1974) and mixed with the bacteria. The suspension was stirred at $0^{\circ} \mathrm{C}$ for $30 \mathrm{~min}$. The bacteria were recovered by centrifuging at $500 \mathrm{~g}$ for $5 \mathrm{~min}$, washed three times with $2 \%(\mathrm{w} / \mathrm{v})$ cycloheptaamylose in phosphate buffer and finally washed three times with phosphate buffer.

A sample of the labelled bacteria was retained for sodium dodecyl sulphate(SDS)-polyacrylamide gel electrophoresis and the remainder was extracted with lithium acetate as described above. The outer membrane complex thus obtained was subjected to SDS-polyacrylamide gel electrophoresis and fluorescent proteins were located using an ultraviolet lamp.

SDS-polyacrylamide gel electrophoresis. Outer membrane complexes and fractions purified from them were subjected to SDS-polyacrylamide gel electrophoresis in the 


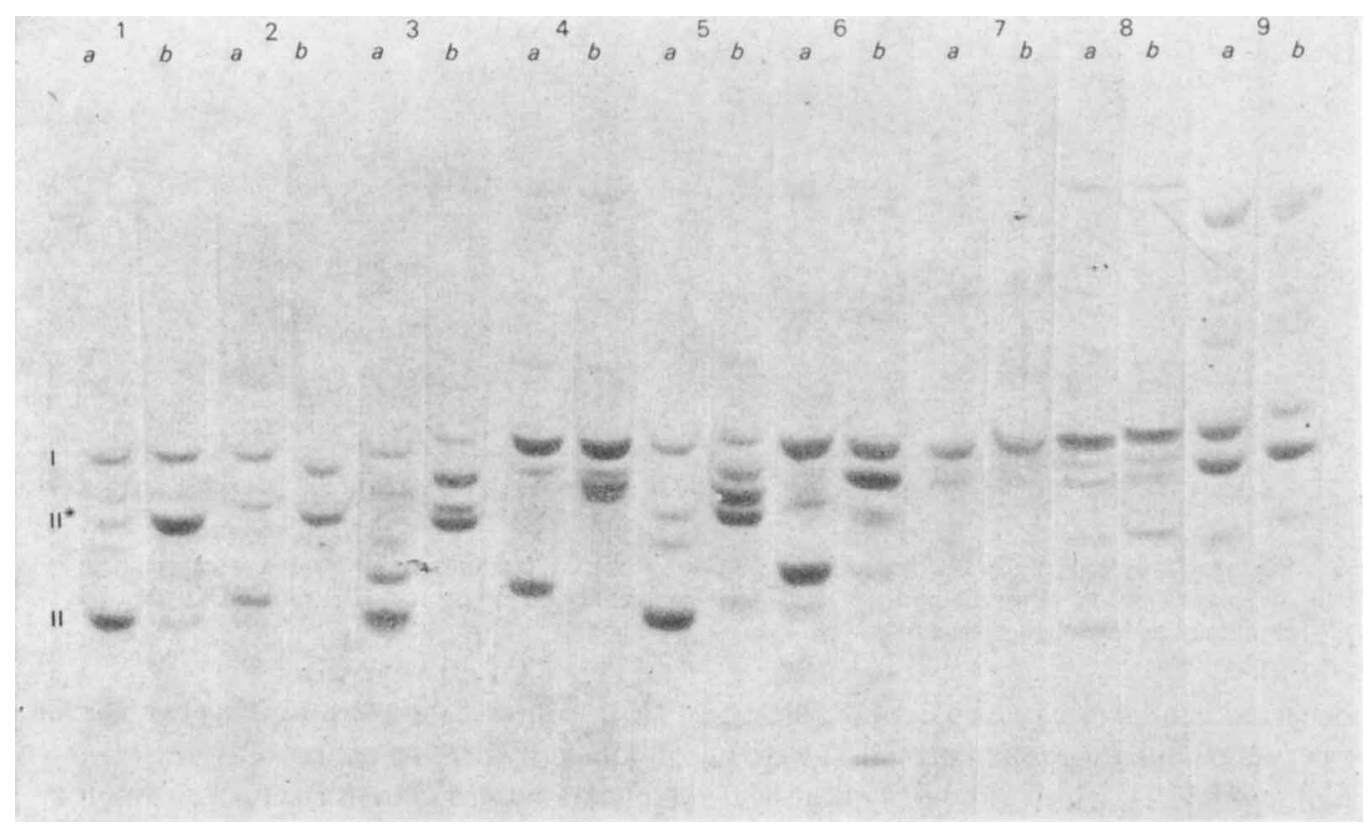

Fig. I. Polyacrylamide gel electrophoresis of outer membrane preparations solubilized with SDS at (a) $37^{\circ} \mathrm{C}$ or $\left(\right.$ b) $100^{\circ} \mathrm{C}$. Neisseria gonorrhoeae strains were: $1, \mathrm{P9} ; 2,24382 ; 3,24606 ; 4,1722 \mathrm{I}$; 5,$24445 ; 6,24207 ; 7$, F62; 8, FA5; 9, 201.

discontinuous system of Laemmli (1970) with tubes of $5 \mathrm{~mm}$ internal diam., using $0.35 \mathrm{ml}$ stacking gel and $\mathrm{I} \cdot 7 \mathrm{ml}$ of $10 \%(\mathrm{w} / \mathrm{v})$ acrylamide separating gel. Samples were solubilized in stock dissociating buffer for $2 \mathrm{~h}$ at $37^{\circ} \mathrm{C}$ or for $5 \mathrm{~min}$ at $100{ }^{\circ} \mathrm{C}$. Electrophoresis was carried out at a constant voltage of $\mathrm{I}$ IO $\mathrm{V}$ until the bromophenol blue tracking dye was about $5 \mathrm{~mm}$ from the end of the tube.

Proteins were detected by staining with Coomassie blue and destaining with propan-2-ol/ acetic acid according to the method of Fairbanks, Steck \& Wallach (197I). Carbohydrates were detected by the periodate-Schiff stain as described by Segrest \& Jackson (1972). Gels were recorded photographically and with a Pye Unicam SPI809 scanning densitometer. Apparent molecular weights were determined using bovine serum albumin, trypsin, lysozyme, ovalbumin and catalase as standards.

Analytical methods. Protein was determined by the method of Lowry et al. (I95I) and total carbohydrate by the phenol-sulphuric acid reaction (Dubois et al., 1956). Phosphate was determined by the method of Chen, Toribara \& Warner (1956) and 2-keto-3-deoxyoctonic acid (KDO) by the thiobarbituric acid reaction (Waravdekar \& Saslaw, 1959). Phospholipid content was determined from the amount of phosphate extracted into chloroform/methanol (2:I, v/v) (Osborn et al., 1972).

\section{RESULTS}

Characterization of the outer membrane complex

SDS-polyacrylamide gel electrophoresis of the material extracted from gonococci with lithium acetate showed that it contained relatively few proteins with one or two dominating (Fig. I, bands I and II). However, the pattern obtained was modified when samples were heated with SDS at $100^{\circ} \mathrm{C}$ for 5 min, instead of $37^{\circ} \mathrm{C}$ for $2 \mathrm{~h}$. Protein 11 disappeared and was replaced by a higher molecular weight protein (Fig. I, band $\mathrm{II}^{*}$ ). This conversion 


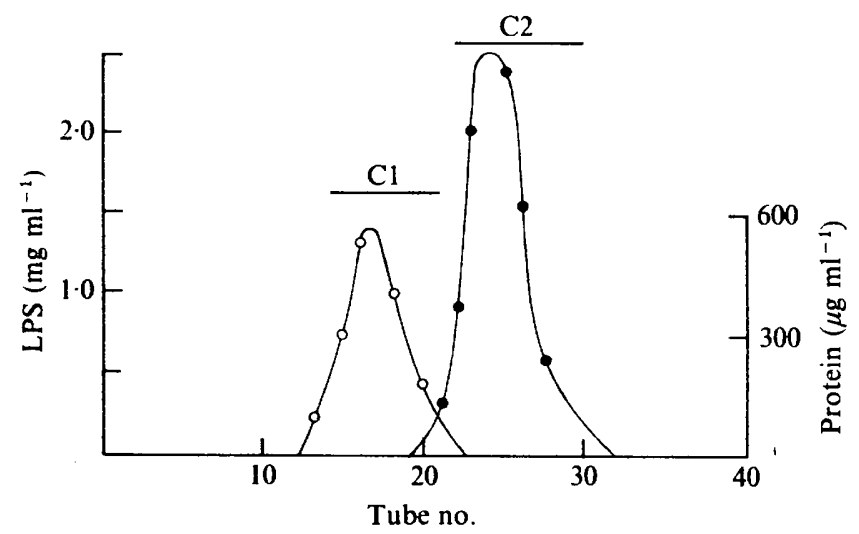

Fig. 2. Chromatography on Sephadex G-75 of material solubilized by cholate treatment of $N$. gonorrhoeae P9 outer membranes. Fractions were analysed for protein $(O)$ and $\mathrm{KDO}(\mathrm{O})$ and combined as indicated by the bars.

occurred in all strains which contained protein II. In contrast the three strains (20I, F62 and FA5) which did not contain protein II were not modified by heating at $100^{\circ} \mathrm{C}$. One strain, P9 (colony type 1 ), which showed typical heat modification, was chosen for further studies.

Analysis of the outer membrane complex showed that it contained protein, LPS and phospholipid in proportions similar to those reported for another strain and had an identical buoyant density of $1 \cdot 22 \mathrm{~g} \mathrm{~cm}^{-3}$ (Johnston \& Gotschlich, 1974). Treatment with SDS at $37^{\circ} \mathrm{C}$ revealed five membrane proteins including major bands with molecular weights of 36500 (I) and 24000 (II), whereas treatment at $100^{\circ} \mathrm{C}$ produced major bands at 36500 (I) and

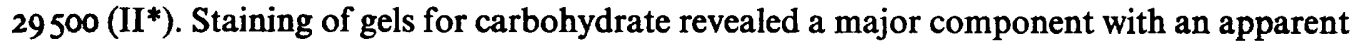
molecular weight of 13000 and a minor component of molecular weight 17000 .

Extraction of bacteria which had been treated with dansyl chloride-cycloheptaamylose produced an outer membrane complex in which the two major proteins were fluorescently labelled. SDS-polyacrylamide gel electrophoresis of the whole bacteria showed over 40 individual proteins of which only three were fluorescent; two corresponded to proteins I and II and the third had a molecular weight corresponding to that of purified pili from strain P9 (Ward \& Robertson, 1976).

\section{Extraction of the outer membrane complex with sodium cholate}

Preliminary experiments showed that the major outer membrane proteins were resistant to extraction by $6 \mathrm{M}$-urea although this served to remove some minor proteins which interfered with subsequent purification steps. Some solubilization occurred with I $\%(v / v)$ Triton X-100 or $\mathrm{I} \%(\mathrm{w} / \mathrm{v})$ sodium cholate; SDS-polyacrylamide gel electrophoresis of the extracts showed the cholate extraction to be more efficient and relatively selective so this procedure was used in larger scale experiments.

Membranes were suspended in $6 \mathrm{M}$-urea in $0.2 \mathrm{M}$-acetate buffer $\mathrm{pH} 6.0(4 \mathrm{ml})$ at $25^{\circ} \mathrm{C}$ at a protein concentration of about $5 \mathrm{mg} \mathrm{ml}^{-1}$. After $30 \mathrm{~min}$ the suspension was centrifuged at $100000 \mathrm{~g}$ for $2.5 \mathrm{~h}$; the supernatant solution which contained $6 \%$ of the original protein and $2 \%$ of the LPS was discarded and the pellet was washed once with $0.2 \mathrm{M}$-acetate buffer pH 6.0. The insoluble material was suspended in $0.1 \mathrm{M}-$ glycine/ $\mathrm{NaOH}$ buffer, $\mathrm{pH} 9.5$, containing $5 \mathrm{Mm}$-EDTA and $\mathrm{I} \%$ (w/v) sodium cholate (cholate buffer) and incubated at $25^{\circ} \mathrm{C}$ for $30 \mathrm{~min}$. The suspension was then centrifuged at $100000 \mathrm{~g}$ for $2.5 \mathrm{~h}$. Analysis 




Fig. 3. Polyacrylamide gel electrophoresis of proteins extracted from the outer membrane of $N$. gonorrhoeae $\mathrm{P9}$ and solubilized with SDS at $(a) 37^{\circ} \mathrm{C}$ or $(b) 100^{\circ} \mathrm{C}$. I. Outer membrane before

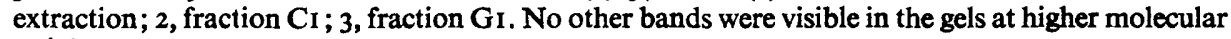
weights.

showed that $50 \%$ of the protein and $90 \%$ of the LPS were solubilized by this treatment. Although the separation was not complete, SDS-polyacrylamide gel electrophoresis showed that the soluble fraction was substantially enriched in protein II whereas the insoluble residue was enriched in protein $I$.

\section{Fractionation of the cholate extract by gel chromatography}

The material solubilized by cholate extraction was applied to a column $(400 \times 15 \mathrm{~mm})$ of Sephadex G-75 and eluted with cholate buffer. Fractions ( $1.5 \mathrm{ml})$ were collected and analysed for protein and KDO. Two peaks were obtained (Fig. 2): the first (CI) contained protein; the second $\left(\mathrm{C}_{2}\right)$ contained $\mathrm{KDO}$, phosphorus and only traces of protein. Peak $\mathrm{C}_{2}$ was further purified by a second passage through the Sephadex G-75 column; fractions were combined and the detergent was removed by extensive dialysis against distilled water. Analysis showed that the final product contained phosphorus, carbohydrate, amino sugars and $\mathrm{KDO}$ in relative proportions similar to those found in the purified LPS extracted from N. gonorrhoeae P9 by aqueous phenol (Stead et al., 1975).

The protein peak $\mathrm{CI}_{\text {I }}$ was concentrated by ultrafiltration on an Amicon PM-Io membrane (Amicon, Oosterhout, Holland), and then applied to a column ( $400 \times 15 \mathrm{~mm})$ of Sephadex G-200 and eluted with cholate buffer. Fractions $(1.5 \mathrm{ml})$ were collected and analysed for protein. A single broad peak was obtained. Samples from alternate tubes were subjected to SDS-polyacrylamide gel electrophoresis and stained for proteins. Tubes 16 to 19 contained one major protein (protein II) together with smaller amounts of other outer membrane proteins; tubes 20 to 28 contained only protein II. The latter fractions were combined and cholate was removed by extensive dialysis to give pure protein II. The identity of peak $\mathrm{CI}_{\mathrm{I}}$ with protein II was confirmed by the observation that the isolated protein exhibited the same heat modification as observed with protein II in outer membranes: treatment with SDS at $37^{\circ} \mathrm{C}$ produced a single band on polyacrylamide gel electrophoresis with an apparent molecular weight of 24000 which was converted to a single band of molecular weight 29500 on heating at $100^{\circ} \mathrm{C}$ for $5 \mathrm{~min}$ (Fig. 3). 


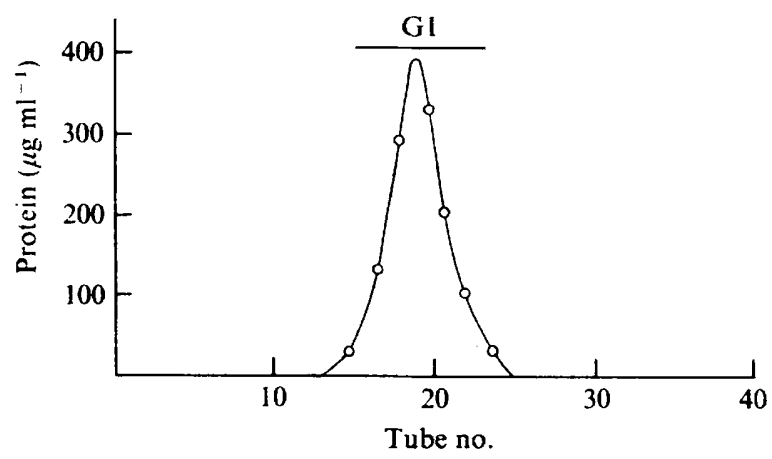

Fig. 4. Chromatography in 6 M-urea on Sephadex G-200 of material solubilized by treating the residue from cholate treatment of $N$. gonorrhoeae $P 9$ outer membranes with guanidine thiocyanate. Fractions were analysed for protein $(O)$ and combined as indicated by the bar.

\section{Extraction of the cholate-insoluble residue with guanidine thiocyanate}

The insoluble residue remaining after extraction with cholate was washed once with water and suspended in $6 \mathrm{M}$-guanidine thiocyanate (Eastman-Kodak, Kirkby, Lancashire) in $10 \mathrm{~mm}$-Tris/ $\mathrm{HCl}, \mathrm{pH} 7 \cdot 8,(5 \mathrm{ml})$ and incubated at $25{ }^{\circ} \mathrm{C}$ for $30 \mathrm{~min}$ (Moldow, Robertson \& Rothfield, 1972). The suspension was centrifuged at $100000 \mathrm{~g}$ for $2 \mathrm{~h}$; the supernatant solution was removed and dialysed against $6 \mathrm{M}$-urea in the same buffer. The non-diffusible fraction was centrifuged at $100000 \mathrm{~g}$ for $2 \mathrm{~h}$. The pellet obtained was combined with the original pellet and subjected to a second extraction. The two soluble fractions were combined and concentrated to 2 to $3 \mathrm{ml}$ by pressure dialysis on an Amicon PM-Io membrane.

The concentrated solution, which contained $56 \%$ of the residual protein, was applied to a column $(450 \times 15 \mathrm{~mm})$ of Sephadex G-200 in $10 \mathrm{~mm}-\mathrm{Tris} / \mathrm{HCl}$ buffer, $\mathrm{pH} 7 \cdot 8$, and eluted with the same buffer. Fractions (I.5 ml) were collected and analysed for protein (Fig. 4). A single broad peak of protein (GI) was eluted in tubes 15 to 25 ; these were pooled and urea was removed by repeated dialysis against water. The final protein suspension was concentrated by pressure dialysis to 2 to $3 \mathrm{ml}$. Samples were treated with SDS at $37^{\circ} \mathrm{C}$ for $2 \mathrm{~h}$ or $100{ }^{\circ} \mathrm{C}$ for $5 \mathrm{~min}$ before polyacrylamide gel electrophoresis. In both cases a single protein band with a molecular weight of 36000 was observed (Fig. 3).

\section{DISCUSSION}

Studies on the outer membrane of Gram-negative bacteria, in particular the enteric bacteria, have generally been done on material prepared by isopycnic centrifugation of spheroplast membranes obtained on lysis of cells with EDTA-lysozyme (Osborn et al., 1972). A similar procedure has been developed for gonococci (Johnston \& Gotschlich, 1974) but was found by Johnston et al. (1976) to produce insufficient material for detailed serological analysis. These authors developed a procedure in which whole cells were extracted with lithium acetate, containing EDTA; this produced material with a chemical composition and buoyant density similar to those of outer membrane prepared by isopycnic centrifugation. The material was further enriched in the major membrane protein by chromatographic separation on Sepharose 6B followed by isoelectric precipitation. This extraction procedure gave a complex containing LPS, the major outer membrane protein and a characteristic secondary protein, and was used to assign clinical isolates of gonococci into 16 distinct serogroups. In this investigation $I$ attempted to separate the major outer membrane 
components in order to study the possible contribution of each to the pathogenicity of the gonococcus. I used a similar procedure to Johnston et al. (1976) to prepare outer membranes, but omitted EDTA from the lithium acetate extraction buffer since preliminary experiments showed that substantial amounts of LPS were also removed from crude cell envelopes by EDTA. The material obtained was similar in gross composition to that of Johnston et al. in that it contained phospholipid, LPS and relatively few proteins.

A number of outer membrane proteins from Gram-negative bacteria show different apparent molecular weights on SDS-polyacrylamide gel electrophoresis, depending on the temperature of solubilization (Osborn et al., 1972; Schnaitman, 1973; Inouye \& Yee, 1973). A similar effect is seem with gonococci (Fig. I). One major protein (I) present in all strains examined was unaffected by heating whereas a second (II), present in six out of the nine strains tested) disappeared on heating at $100{ }^{\circ} \mathrm{C}$ for $5 \mathrm{~min}$ with the concomitant appearance of another band (II*) of higher molecular weight. This anomaly is clearly due to conversion of a single protein to one of two alternative forms dependent on the temperature of solubilization, since purified protein II isolated from strain P9 showed identical behaviour (Fig. 3). The reason for this is not clear but is likely that some hydrophobic outer membrane proteins are fully converted to the rigid rod conformation only on boiling with SDS (Schnaitman, 1973) while others react completely at $37^{\circ} \mathrm{C}$. Despite the modification which occurs on boiling, no additional proteins are solubilized by this treatment; thus gonococci behave in a similar manner to the nonpathogenic Neisseria and in contrast to $E$. coli which contains outer membrane proteins which are not solubilized at $37^{\circ} \mathrm{C}$ (Russell, Johnson \& McDonald, 1975). The presence of proteins which are modified on heating makes it difficult to compare other investigations on gonococcal outer membrane proteins, particularly since partial conversion of one form to another would cause the artefactual appearance of multiple peaks. In this study, heating at $100{ }^{\circ} \mathrm{C}$ for $5 \mathrm{~min}$ (Russell et al., I975, completely converted protein $\mathrm{II}$ to $\mathrm{II}^{*}$, whereas on heating at $70^{\circ} \mathrm{C}$ for $20 \mathrm{~min}$ (Wolf-Watz et al., 1975) conversion was only about $50 \%$ and was not always complete on heating at $100{ }^{\circ} \mathrm{C}$ for only I min (Johnston et al., 1976). The location of proteins I and II on the bacterial surface was confirmed by the observation that when whole gonococci of strain P9 were fluorescence labelled by treatment with dansyl chloride-cycloheptaamylose complex, the label was confined to proteins 1 and II and to pili. This reagent, which has been used to label plasma membranes, is presumably unable to penetrate the cell because of its large molecular size and so only reacts with those proteins exposed at the surface (Kinoshita et al., 1974).

The outer membranes used by Johnston et al. (1976) to assign gonococci into 16 serogroups contained a single major protein which, after boiling in SDS, had an apparent molecular weight characteristic of the serogroup in the range 32000 to 39000 . In this study, most preparations had the two major proteins I and II, although in some strains protein II was missing (Fig. I). On the basis of molecular weight data it appears that protein $I$ is the single major protein previously reported. The reason for this difference is not clear but it is intriguing to observe that in the limited number of strains examined, protein 11 is present in all those originally isolated in Great Britain and is absent from those obtained from the United States (F62, FA5, 20I). Unfortunately, too few strains were examined for further significance to be attached to this observation.

Studies on the individual surface components of other Gram-negative bacteria have generally utilized relatively harsh conditions, particularly the denaturing detergent SDS, to dissociate outer membranes before attempting separation of the components (Schnaitman, 1974; Hindennach \& Henning, 1975). In this study I used the milder detergent, sodium 
cholate. This provided a useful initial separation since protein II and LPS were solubilized by this procedure while protein I was not. Further fractionation was then achieved by gel filtration in cholate-containing buffer to give pure LPS and protein II fractions. The inclusion of LPS into Sephadex G-75 indicates that it is broken down into monomeric units by the action of bile salt detergents in a similar manner to other lipopolysaccharides (Ribi et al., 1966). A similar procedure has recently been used to isolate antigenically active fractions from the outer membrane of Bacteroides fragilis (Kasper \& Seiler, I975). Protein I could be extracted with guanidine thiocyanate and purified in the presence of urea to give a homogeneous protein, a procedure which is reported to preserve antigenic activity (Moldow et al., 1972). Thus the outer membrane of strain P9 can be fractionated by relatively mild methods to give three major surface components which are likely to be intimately involved in the interaction of the gonococcus with its host. Indeed preliminary experiments indicate that these components are among the major antigenic determinants of the strain (P. Lambden, unpublished observations). Previous attempts at serological classification of gonococci have utilized LPS (Glynn \& Ward, 1970), pili (Buchanan, 1975; Novotny \& Turner, 1975) and a major outer membrane protein (Johnston et al., 1976), but several of these preparations were heterogeneous. The methods described here should allow production of purer antigens and perhaps extend the specificity of these tests. In particular the observation that LPS is readily dissociated in cholate buffer should allow this component to be removed without denaturing protein antigens.

This work was supported by an M.R.C. programme grant. I should like to thank Professor P. J. Watt for his stimulating interest in this work and Mrs J. S. Everson for her skilful technical assistance in preparing outer membranes.

\section{REFERENCES}

Buchanan, T. M. (1975). Antigenic heterogeneity of gonococcal pili. Journal of Experimental Medicine 14r, 1470-1475.

Buchanan, T. M., Swanson, J., Holmes, K. K., Kraus, S. J. \& Gotschlich, E. C. (1973). Quantitative determination of antibody to gonococcal pili: changes in antibody levels with gonococcal infection. Journal of Clinical Investigation 52, 2896-2909.

Chen, P.S., Toribara, T. Y. \& Warner, H. (1956). Micro determination of phosphorus. Analytical Chemistry 28, 1756-1758.

Dubois, M., Ginles, K. A., Hamilon, J. K., Rebers, P. A. \& Smith, F. (1956). Colorimetric method for the determination of sugars and related substances. Analytical Chemistry 28, 350-356.

Fairbanks, G., Steck, T. L. \& Wallach, D. F. H. (1971). Electrophoretic analysis of the major polypeptides of the human erythrocyte membrane. Biochemistry 10, 2606-26I 7.

GLYNN, A. A. \& WARD, M.E. (1970). Nature and heterogeneity of the antigens of Neisseria gonorrhoeae involved in the serum bactericidal reaction. Infection and Immunity 2, 162-168.

Heckels, J. E., Blackett, B., Everson, J. S. \& WARD, M. E. (1976). The influence of surface charge on the attachment of Neisseria gonorrhoeae to human cells. Journal of General Microbiology 96, 359-364.

HINDENNACH, I. \& HENNING, U. (1975). The major proteins of the Escherichia coli outer cell envelope membrane. Preparative isolation of all major membrane proteins. European Journal of Biochemistry 59, 207-213.

INOUYE, M. \& YEE, M. L. (1973). Homogeneity of envelope proteins of Escherichia coli separated by gel electrophoresis in sodium dodecyl sulphate. Journal of Bacteriology 113, 304-312.

Johnston, K. H. \& GoTsCHLICH, E. C. (1974). Isolation and characterisation of the outer membrane of Neisseria gonorrhoeae. Journal of Bacteriology 119, 250-257.

Johnston, K. H., Holmes, K. K. \& Gotschlich, E. C. (1976). The serological classification of Neisseria gonorrhoeae. I. Isolation of the outer membrane complex responsible for serotypic specificity. Journal of Experimental Medicine 143, 74I-758.

KASPER, D. L. \& SEILER, M. W. (1975). Immunochemical characterisation of the outer membrane complex of Bacteroides fragilis subspecies fragilis. Journal of Infectious Diseases 123, 440-450.

Kellogg, D. S., Peacock, W. L., Deacon, W. E., Brown, L. \& Pirkle, C. I. (1963). Neisseria gonorrhoeae. I. Virulence genetically linked to the clonal variation. Journal of Bacteriology 85, I274-I 279. 
KinoshitA, T., IINUmA, F., Tsuj, A. (1974). Fluorescent labeling of proteins and a plasma membrane using cycloheptaamylose dansyl chloride complex. Analytical Biochemistry 6r, 632-537.

LAEMMLI, U. K. (1970). Cleavage of structural proteins, during the assembly of the head of bacteriophage T4. Nature, London 227, 680-685.

Lowry, O. H., Rosebrough, N. J., Farr, A. L. \& Randall, R. J. (I951). Protein measurement with the Folin phenol reagent. Journal of Biological Chemistry I93, 265-275.

Moldow, C., Robertson, J. \& Rothrield, L. (1972). Purification of bacterial membrane proteins; the use of guanidium thiocyanate and urea. Journal of Membrane Biology ro, I37-I 52.

NovotNY, P. \& TURNER, W. H. (1975). Immunological heterogeneity of pili of Neisseria gonorrhoeae Journal of General Microbiology 89, 87-92.

Osborn, M. J., GANDer, J. E., PARISI, E. \& CARson, J. (1972). Mechanism of assembly of the outer membrane of Salmonella typhimurium, isolation and characterisation of cytoplasmic and outer membrane. Journal of Biological Chemistry 247, 3962-3972.

Ribi, E., Anacker, R. L., Brown, R., Haskins, W. T., Malgren, B., Milner, K. C. \& Rudbach, J. A. (1966). Reaction of endotoxin and surfactants. I. Physical and biological properties of endotoxin treated with sodium deoxycholate. Journal of Bacteriology 92, 1493-1509.

Russell, R. B. R., Johnson, K. G. \& MCDonald, I. J. (1975). Envelope proteins in Neisseria. Canadian Journal of Microbiology 2r, 1519-1534.

SCHNAITMAN, C. A. (1973). Outer membrane proteins of Escherichia coli. I. Effect of preparative conditions on the migration of protein in polyacrylamide gels. Archives of Biochemistry and Biophysics 157, 54I-552.

Schnartman, C. A. (1974). Outer membrane proteins of Escherichia coli. III. Evidence that the major protein of Escherichia coli or I I outer membrane consists of four distinct polypeptide species. Journal of Bacteriology 118, 442-453.

SEgREST, J. P. \& JACKSON, R. L. (1972). Molecular weight determination of glycoproteins by polyacrylamide gel electrophoresis in sodium dodecyl sulphate. Methods in Enzymology 28, 54-63.

Stead, A., Main, J. S., Ward, M. E. \& Watt, P. J. (1975). Studies on lipopolysaccharides isolated from strains of Neisseria gonorrhoeae. Journal of General Microbiology 88, 123-131.

WaravdekaR, V.S. \& Saslaw, L. D. (1959). A sensitive colorimetric method for the estimation of 2-deoxysugars with the use of malonaldehyde-thiobarbituric acid reaction. Journal of Biological Chemistry 234, 1945-1950.

WARd, M. E. \& Robertson, J. N. (I976). Preparation and properties of gonococcal pili. Proceedings of the Society for General Microbiology 3, 94-95.

Wolf-Watz, H., Elmos, T., Nomark, S. \& Bloom, G. D. (1975). Cell envelope of Neisseria gonorrhoeae: outer membrane and peptidoglycan composition of penicillin-sensitive and resistant strains. Infection and Immunity I1, 1332-1341.

White, L. A. \& Kellogg, D.S. (1965). Neisseria gonorrhoeae identification in direct smears by a fluorescent antibody-counterstain method. Applied Microbiology 13, I 71-I 74 . 